\title{
PEDOLOGICAL CHARACTERISTICS, GENERAL FERTILITYAND CLASSIFICATION OF SOME BENCHMARK SOILS OF MOROGORO DISTRICT, TANZANIA
}

\author{
Balthazar M. Msanya ${ }^{1}$, Abel K. Kaaya ${ }^{1}$, Shigeru Araki ${ }^{2}$, Hiroo Otsuka ${ }^{3}$ and Gerson I. Nyadzi ${ }^{1}$ \\ ${ }^{1}$ Sokoine University of Agriculture, Faculty of Agriculture, \\ Department of Soil Science, P.O. Box 3008, Morogoro, TANZANIA \\ ${ }^{2}$ Graduate School of Asian and African Area Studies, Kyoto University, \\ 46 Shimoadachi-cho, Sakyo-ku, Kyoto, 606-8501, JAPAN \\ ${ }^{3}$ Center for Cooperative Research and Development, Kobe University, \\ 1-1, Rokkodai, Nada-ku, Kobe 657-8501, JAPAN
}

\begin{abstract}
A detailed characterization of soils earmarked as "Benchmark Soils of Morogoro District", Tanzania, was carried out to provide data required for planning and execution of soil fertility studies and transfer of agro-technology in the area. Benchmark soils are defined as those occurring in extensive areas and whose comprehensive characterization could contribute substantially to transfer of agro-technology from one area to another. Eleven sites were selected as "Benchmark Sites" of the district based on existing soils information coupled with reconnaissance field soil survey. Soil samples representative of the benchmark soil profiles were described and analysed for their chemical, physical and mineralogical characteristics. Based on these data, general fertility is discussed for the various soils pointing out their potentials and constraints. The data also permitted classification of the soils using international soil classification systems i.e. the United States Department of Agriculture Soil Taxonomy and the FAO-UNESCO Soil Classification System. The soils were classified into different categories reflecting their differences in potentials and constraints and hence use and management. The data obtained through this study presents a substantial base for sound land use planning and will facilitate transfer of technology from one area to another with similar ecological conditions.
\end{abstract}

Key words: Pedological characteristics, fertility, soil classification, benchmark soils, Morogoro District, Tanzania

\section{INTRODUCTION}

Soil information gathered by systematic identification, grouping and delineation of different soils is required when sound interpretations towards land use potential are to be made. In addition, climatic and other ecological characteristics as well as socio-economic factors are also important elements in land management. A good data bank on soil properties and related site characteristics is inevitable for one to be able to advise both current and potential land users on how to use the land in the best possible way. Soil fertility specialists need well characterized sites with similar soil and other ecological conditions in order to carry out meaningful fertilizer trials.

Although Tanzania has long history of collecting basic information on soil characterization in the form of soil surveys (Msanya et al., 1991; Msanya and Magoggo, 1993; Kilasara et al., 1994), this has only been concentrated in a few selected high potential areas. Thus, the available information remains rather scanty relative to the large size of the country and its diverse soil and other land resources. The few existing soil resource inventories are characterized by their small scale nature 
with high level of generalization, being based on rather few observations scattered over large areas. Moreover, these works have been done using different methodologies and criteria. Inevitably, most existing studies cannot easily be correlated and do not have sufficient predictive value. There is need for more efforts to be invested in coordinated and systematic inventory of the country's soils and other land resources to facilitate land use planning activities. There is also a strong feeling that fertilizer trials should be done on well characterized soils to enhance transferability of information from one place to another.

This study dwells on pedological characterization and general fertility evaluation of "Benchmark Soils of Morogoro District”. By definition benchmark soils are those occurring in extensive areas so that their comprehensive characterization will contribute substantially to agricultural and other developments of the district. Information on benchmark soils and the results of experiments carried out on them can be extended to many of those soils closely related in classification and geography. Such soils can be used as standards for widespread application and are key to agro-technology transfer.

Selection of benchmark soils is very crucial and requires rigorous soil mapping to show their spatial distribution. Although at the inception of the project there was limited base information on geographical distribution of land resources, current developments in the mapping of soils and other land resources of Morogoro rural and urban districts (Kimaro et al., 2001; Msanya et al., 2001a,b,c) has greatly facilitated to show their spatial distribution and consequently simplified land use planning exercises for the area.

The specific objectives of this study were three-fold:

1. to characterize the benchmark soils in terms of their chemical, physical and mineralogical characteristics and hence their general fertility;

2. to classify the soils using the United States Department of Agriculture (USDA) Soil Taxonomy and the FAO-Unesco Classification System;

3. to provide data that will be utilized for development of soil/land management technologies such as fertilizer application, soil conservation and improved tillage methods.

\section{MATERIALS AND METHODS}

\section{The study area}

The study area is located in the north-western part of Morogoro District, Tanzania. Figure 1 presents the location of the studied soil profiles, while Table 1 gives details of the site characteristics. The climate of Morogoro District can generally be described as a subhumid tropical type. The mean annual rainfall of the studied sites varies from about $750 \mathrm{~mm}$ (Melela) to about $1050 \mathrm{~mm}$ (Pangawe). Most areas in the district experience bimodal rainfall pattern characterized by two rainfall peaks in a year with a definite dry season separating the short and long rains. The short rain season is from October to December while the long rain season starts from March and ends in May. The onset of both rains and their distribution are irregular and unreliable. The soil moisture regime in most places is ustic except where there are local effects of flooding and waterlogging. Figure 2 gives rainfall data for the various studied sites. Information on temperatures (Kaaya et al., 1994) shows that the mean annual air temperature (MAAT) for most places in the district is about $24^{\circ} \mathrm{C}$ and the mean annual soil temperature (MAST) is characterized as iso-hyperthermic.

\section{Field methods}

Selection of benchmark sites was done using existing soil information on Morogoro soils (De Pauw, 1984; Kaaya et al., 1994; Moberg et al., 1982; Msanya, 1980 \& 1991; Msanya and Msaky, 1983; National Soil Service, 1986 \& 1988) coupled with reconnaissance field observations in various parts of the district. Geological and geomorphological parameters were used to facilitate the selection. Eleven soil profiles were identified, excavated, described and sampled following standard procedures (FAO, 1977; Munsell Color Company, 1954; Soil Survey Staff, 1951). Exact locations of the sites in terms of international coordinates were determined using Sony Global Positioning System (GPS) Receiver.

\section{Routine laboratory methods}

Chemical and physical analyses were done as follows: $\mathrm{pH}$ was measured potentiometrically in water and in $1 \mathrm{M}$ $\mathrm{KCl}$ at the ratio 1/2.5 soil-water and soil-KCl. Organic carbon was determined by wet oxidation method of 
Pedological Characteristics, General Fertility and Classification of some Benchmark Soils of Morogoro District, Tanzania

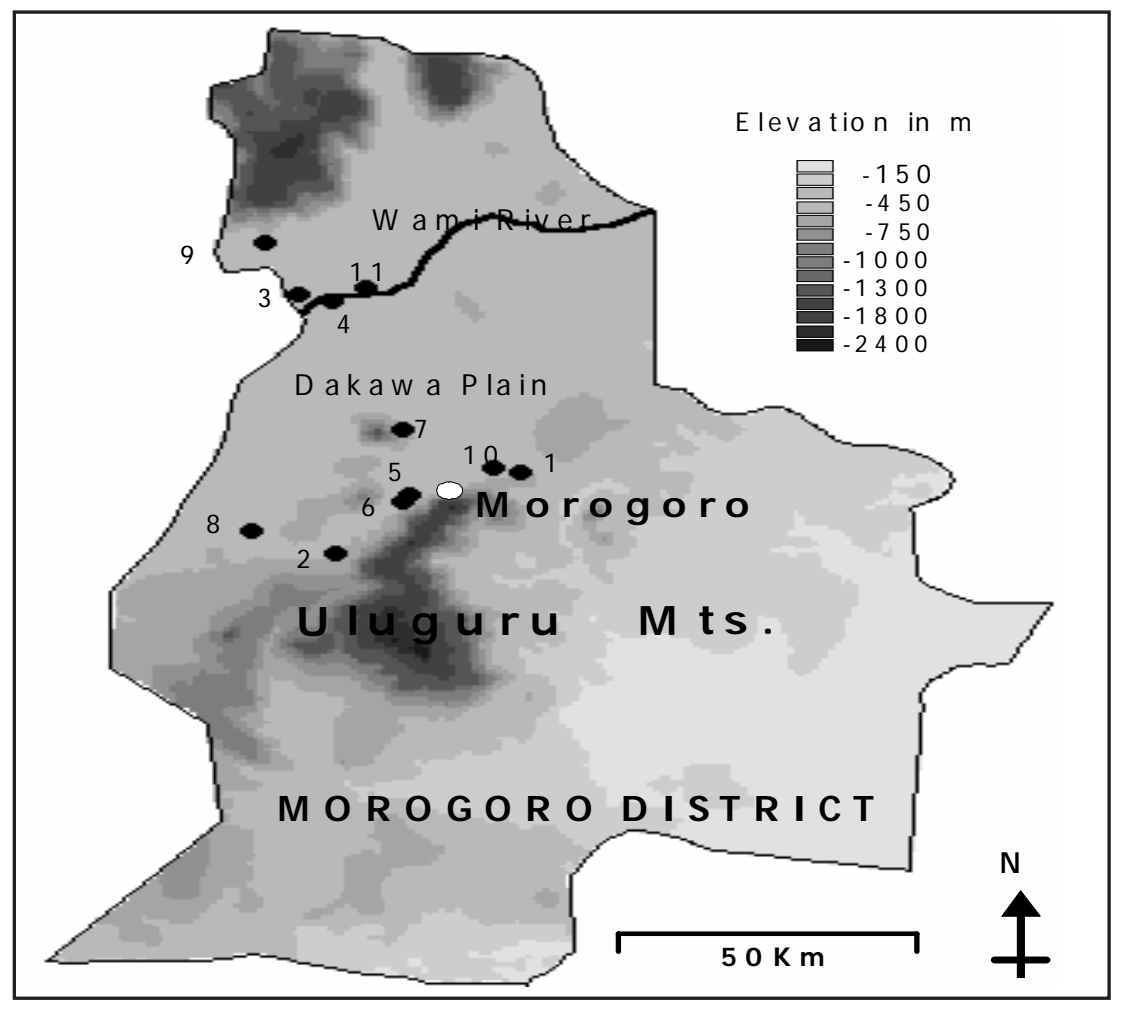

Fig. 1: Location of studied soil profiles

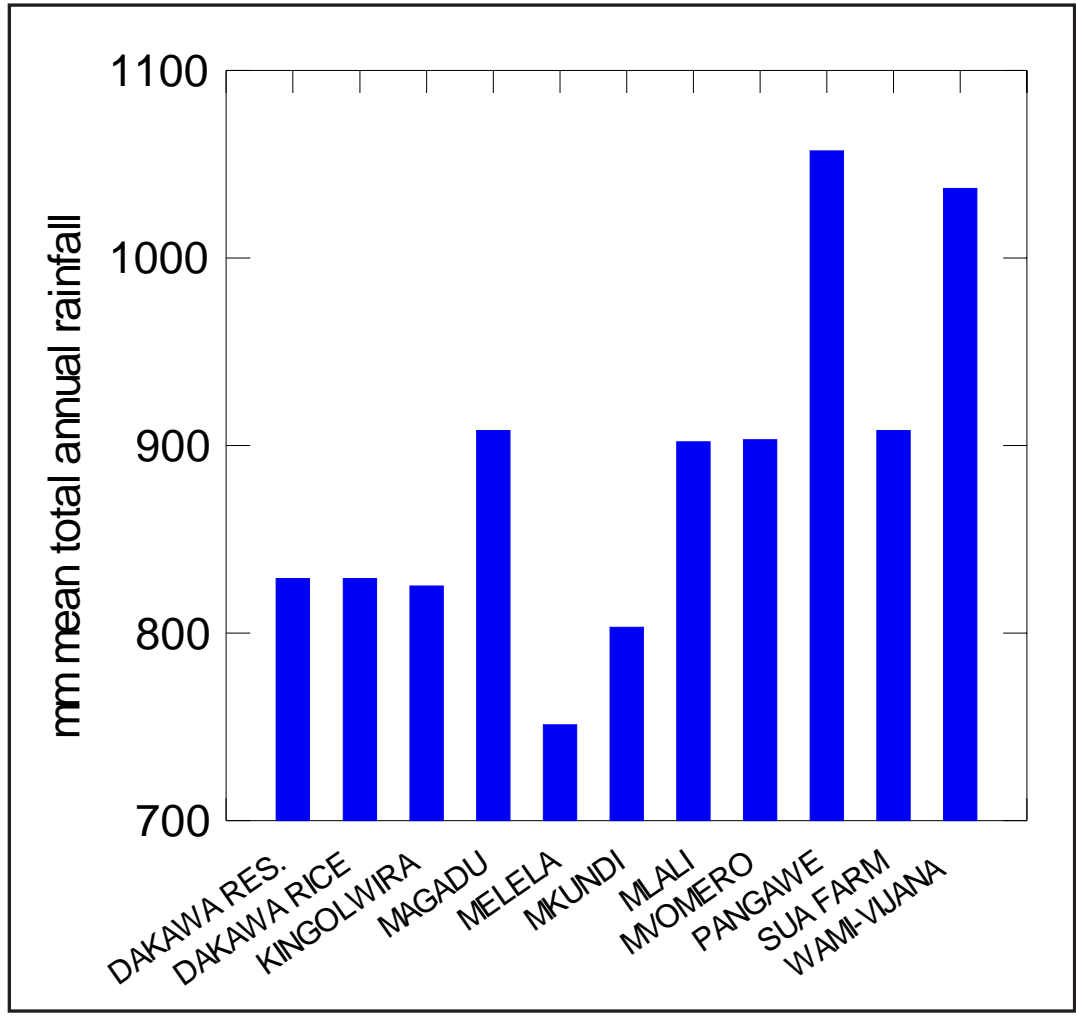

Fig. 2: Rainfall data for the studied sites 
Table 1. Detailed sites characteristics of the district

\begin{tabular}{|c|c|c|c|c|c|c|c|}
\hline Pedon no & Site name & Location & $\begin{array}{l}\text { Altitude } \\
\text { (masl) }\end{array}$ & Physiography & Soil parent materials & Vegetation / land use & Soil moisture regime \\
\hline 1 & Kingolwira & $\begin{array}{l}\mathrm{S}_{0}^{0} 6^{0} 47^{\prime} 35.2^{\prime \prime} ; \\
\mathrm{E}^{0} 7^{0} 48^{\prime} 26.6^{\prime \prime}\end{array}$ & 490 & $\begin{array}{l}\text { Plain, almost flat, } \\
\text { slope }<2 \%\end{array}$ & $\begin{array}{l}\text { Neogene colluvium derived from } \\
\text { metasedimentary rocks rich in } \\
\text { garnet-biotite gneisses with } \\
\text { microcline and muscovite }\end{array}$ & $\begin{array}{l}\text { Maize crop (already } \\
\text { harvested) }\end{array}$ & ustic \\
\hline 2 & Mlali & $\begin{array}{l}\text { S } 06^{0} 57^{\prime} 49.3^{\prime \prime} ; \\
\text { E } 370 \text { 32' 44.0" }\end{array}$ & 590 & $\begin{array}{l}\text { Almost flat to flat } \\
\text { land, slope about } \\
2 \%\end{array}$ & $\begin{array}{l}\text { Neogene colluvium derived from } \\
\text { micaceous gneisses and } \\
\text { hornblende gneisses and granulites }\end{array}$ & $\begin{array}{l}\text { Grass and bush fallow } \\
\text { with Hyperrhenia } \\
\text { grass and Acacia spp. }\end{array}$ & ustic \\
\hline \multirow[t]{2}{*}{3} & $\begin{array}{l}\text { Wami-Vijana } \\
\text { Prison }\end{array}$ & $\begin{array}{l}\text { S } 06^{0} 24^{\prime} 46.5^{\prime \prime} ; \\
\text { E } 37^{0} 28^{\prime} 16.9^{\prime \prime}\end{array}$ & 380 & $\begin{array}{l}\text { Part of Wami Flats, } \\
\text { flat land, slope }< \\
1 \%\end{array}$ & $\begin{array}{l}\text { Neogene complex alluvium of } \\
\text { diverse origin and composition }\end{array}$ & Sorghum & aquic \\
\hline & $\begin{array}{l}4 \text { Dakawa Res. } \\
\text { Station }\end{array}$ & $\begin{array}{l}\text { S } 06^{0} 25^{\prime} 35.1^{\prime \prime} ; \\
\text { E } 37^{0} 32^{\prime} 28.8^{\prime \prime}\end{array}$ & 360 & $\begin{array}{l}\text { Mbuga flat (part of } \\
\text { Wami flats), slope } \\
<1 \%\end{array}$ & $\begin{array}{l}\text { Neogene alluvium of diverse origin } \\
\text { forming mbuga soils with deep wide } \\
\text { cracks }\end{array}$ & Irrigated rice & aquic \\
\hline 5 & SUA Farm & $\begin{array}{l}\text { S } 06^{0} 50^{\prime} 24.7^{\prime \prime} ; \\
\text { E } 37^{0} 38^{\prime} 59.8^{\prime \prime}\end{array}$ & 526 & $\begin{array}{l}\text { Colluvial plain, } \\
\text { almost flat, slope } \\
1 \%\end{array}$ & $\begin{array}{l}\text { Neogene colluvium derived from } \\
\text { plagioclase and quartz-rich } \\
\text { metasedimentry rocks }\end{array}$ & $\begin{array}{l}7 \text { year fallow; currently } \\
\text { under Eucalyptus spp. } \\
\text { and Hyperrhenia spp. }\end{array}$ & ustic \\
\hline 6 & Magadu & $\begin{array}{l}\text { S } 06^{0} 51^{\prime} 15.0^{\prime \prime} ; \\
\text { E } 37^{0} 38^{\prime} 33.1^{\prime \prime}\end{array}$ & 540 & $\begin{array}{l}\text { Undulating convex } \\
\text { land, slope at site } \\
\text { about } 4 \%\end{array}$ & $\begin{array}{l}\text { Neogene colluvium derived from } \\
\text { plagioclase and quartz-rich } \\
\text { metasedimentary rocks }\end{array}$ & Maize & ustic \\
\hline 7 & Mkundi & $\begin{array}{l}\text { S } 06^{\circ} 42^{\prime} 01.4^{\prime \prime} \\
\text { E } 37^{\circ} 38^{\prime} 22.5\end{array}$ & 576 & $\begin{array}{l}\text { Undulating } \\
\text { concave land, } \\
\text { slope at site } 3-4 \%\end{array}$ & $\begin{array}{l}\text { Neogene alluvio-colluvial } \\
\text { superficial sands and sandy } \\
\text { hillwash derived from banded } \\
\text { muscovite-boitite migmatites }\end{array}$ & $\begin{array}{l}\text { Maize, sorghum and } \\
\text { cassava }\end{array}$ & ustic \\
\hline 8 & Melela & $\begin{array}{l}\text { S } 06^{\circ} 54^{\prime} 57.2^{\prime \prime} ; \\
\text { E } 37^{\circ} 25^{\prime} 30.6^{\prime \prime}\end{array}$ & 490 & $\begin{array}{l}\text { Alluvial plain, } \\
\text { almost flat with a } \\
\text { gentle slope of } \\
\text { about } 1 \%\end{array}$ & $\begin{array}{l}\text { Neogene alluvium of diverse origin } \\
\text { compris ing superficial deposits of } \\
\text { mbuga and alluvial soils }\end{array}$ & $\begin{array}{l}\text { Cotton, sorghum, and } \\
\text { maize }\end{array}$ & ustic \\
\hline 9 & Mvomero & $\begin{array}{l}\text { S } 06^{\circ} 18^{\prime} 04.6^{\prime \prime} \\
\text { E } 37^{\circ} 26^{\prime} 38.7^{\prime \prime}\end{array}$ & 414 & $\begin{array}{l}\text { Almost flat land, } \\
\text { slope } 0 \text { - } 1 \%\end{array}$ & Mica-rich alluvium of diverse origin & $\begin{array}{l}\text { Maize, mangoes, } \\
\text { coconuts }\end{array}$ & aquic \\
\hline 10 & Pangawe & $\begin{array}{l}\text { S } 06^{\circ} 47^{\prime} 01.5^{\prime \prime} \\
\text { E } 37^{\circ} 46^{\prime} 11.1^{\prime \prime}\end{array}$ & 530 & $\begin{array}{l}\text { Almost flat land, } \\
\text { slope at site about } \\
1 \%\end{array}$ & $\begin{array}{l}\text { Neogene alluvio-colluvium derived } \\
\text { from metasedimentary rocks rich in } \\
\text { hornblende-pyroxene granulites }\end{array}$ & Maize & ustic \\
\hline 11 & $\begin{array}{l}\text { Dakawa Rice } \\
\text { Farms }\end{array}$ & $\begin{array}{l}\text { S } 06^{\circ} 23^{\prime} 55.7^{\prime \prime} ; \\
\text { E } 37^{\circ} 35^{\prime} 12.4^{\prime \prime}\end{array}$ & 360 & $\begin{array}{l}\text { Flat land (part of } \\
\text { Wami flats), slope } \\
<1 \%\end{array}$ & $\begin{array}{l}\text { Neogene alluvium of diverse origin } \\
\text { which on site form gray and black } \\
\text { mbuga soils }\end{array}$ & $\begin{array}{l}\text { Rice, currently } \\
\text { abandoned due to salt }\end{array}$ & aquic \\
\hline
\end{tabular}

Walkley and Black (Nelson and Sommers, 1982) and converted to organic matter by multiplying by a factor of 1.724. Kjeldahl method (Bremner and Mulvaney, 1982) was employed to determine total nitrogen. Phosphorus was extracted by Bray and Kurtz-1 method (Bray and Kurtz, 1945) and determined spectrophotometrically (Murphy and Riley, 1962; Watanabe and Olsen, 1965). The cation exchange capacity (CEC) and exchangeable bases were extracted by saturating soil with neutral $1 \mathrm{M}$ $\mathrm{NH}_{4} \mathrm{OAc}$ (Thomas, 1982) and the adsorbed $\mathrm{NH}_{4}^{+}$ displaced with $\mathrm{K}^{+}$using $1 \mathrm{M} \mathrm{KCl}$ and then determined by Kjeldahl distillation method for the estimation of CEC of soil. The bases $\mathrm{Ca}^{++}, \mathrm{Mg}^{++}, \mathrm{Na}^{+}$, and $\mathrm{K}^{+}$, displaced by $\mathrm{NH}_{4}^{+}$were measured by atomic absorption spectrophotometer. Texture was determined by Bouyoucos hydrometer method (Day, 1965) after dispersing soil with sodium hexametaphosphate. Bulk density was determined using core sample method (Blake, 1965).

\section{Clay mineralogy and total element analysis}

Samples for clay mineralogical analysis were prepared using the method outlined by Msanya et al. (1998) follows: fine-earth subsoil samples were first treated with $30 \% \mathrm{H}_{2} \mathrm{O}_{2}$ to remove organic matter. The samples were then thoroughly dispersed by ultra-sonic vibrations for 5 minutes after adding $1 \mathrm{ml}$ of $1 \mathrm{M} \mathrm{NaOH}$ (dispersing agent) and then $300 \mathrm{ml}$ of deionised water. The suspensions were transferred to glass cylinders and their volumes made up to $1000 \mathrm{ml}$ and then allowed to settle. At appropriate time interval and depth, clay samples were siphoned out of the 
Pedological Characteristics, General Fertility and Classification of some Benchmark Soils of Morogoro District, Tanzania

cylinders into glass beakers. The clay samples were mounted on glass slides for $\mathrm{x}$-ray diffraction analysis. X-ray diffractometer model Rigaku D/Max-1000 was used for the analysis and the $\mathrm{x}$-ray diffractograms plotted by computer model Rigaku 2050/32. The relative quantitative mineralogical compositions were estimated from the diffractograms.

The total elemental composition of fine-earth subsoil samples was determined by $\mathrm{x}$-ray florescence spectrometry using a Rigaku-denki KG-4 x-ray spectrometer (Dixon and Weed, 1989). Ten elements namely $\mathrm{Fe}, \mathrm{Ti}, \mathrm{Mn}, \mathrm{Ca}, \mathrm{K}, \mathrm{P}, \mathrm{Si}, \mathrm{Al}, \mathrm{Mg}$ and $\mathrm{K}$ were determined and expressed in the form of oxides.

\section{Classification of the studied soils}

Using both field and laboratory data the soils were classified up to family level of the USDA Soil Taxonomy (Soil Survey Staff, 1990) and to level-2 of the FAOUnesco (1989) Soil Classification System.

\section{RESULTS AND DISCUSSIONS}

\section{Chemical and physical characteristics and general fertility of the soils}

The chemical and physical properties of the studied soils are presented in Table 2. General soil fertility was evaluated based on the standards set by EUROCONSULT (1989) and Landon (1991).

Pedons 1, 2, 5 and 6 are very deep and well drained, predominantly clayey soils with very low organic carbon and phosphorus contents and low to very low nitrogen contents. Exchangeable $\mathrm{K}, \mathrm{Ca}$ and $\mathrm{Mg}$ appear to be adequate at present although the subsoil acidity may cause some alarm. In pedons 5 and 6 the subsoils are marginal to deficient in Ca and Mg. Both topsoil and subsoil have a friable consistence. The base saturation in the four pedons can be rated as medium in the epipedons and low in the subsoils, whereas the CEC is mostly low throughout the profiles. Non-acidifying $\mathrm{N}$ and $\mathrm{P}$ fertilizers and liming will be necessary for optimal crop production on these soils.

Pedons 3, 4 and 11 are very deep and imperfectly drained, predominantly clayey soils with low to very low OC, $\mathrm{N}$ and $\mathrm{P}$ and have firm to very firm consistence. Pedon 3 has adequate amounts of $\mathrm{K}, \mathrm{Ca}$ and $\mathrm{Mg}$ and a favourable $\mathrm{pH}$. In the case of pedon 4, Ca, $\mathrm{Mg}$ and $\mathrm{K}$ are adequate, although there is an imbalance of $\mathrm{K}$ and $\mathrm{Mg}$. In pedon 11 ,
$\mathrm{Ca}$ and $\mathrm{Mg}$ are adequate while $\mathrm{K}$ is marginal with a possibility of imbalance with Mg. The base saturation in the three pedons is high to very high throughout the profiles, while the CEC is medium in the upper $50 \mathrm{~cm}$ and low in the subsoil of pedon 3 and medium to high throughout pedons 4 and 11 . Fertilization to supply $\mathrm{N}$ and $\mathrm{P}$ may be necessary for optimal plant growth.

Pedon 7 is a very deep soil showing evidences of somewhat poor drainage and having a friable to very friable sandy loam to sandy clay loam topsoil overlying a firm clayey subsoil. The soil has very low $\mathrm{N}$ and $\mathrm{P}$ contents and will require substantial fertilizer additions to supply these nutrients. $\mathrm{Ca}$ and $\mathrm{Mg}$ levels are adequate but $\mathrm{K}$ appears marginal. The base saturation is low in the upper $50 \mathrm{~cm}$ and high to very high deeper in the profile while the CEC is low in the upper $50 \mathrm{~cm}$ and medium deeper down the profile.

Pedon 8 is a very deep black mbuga soil with a firm consistence and a predominantly sandy clay topsoil and subsoil texture. There are clear evidences of wide and deep cracking and gilgai micro-relief. OC, $\mathrm{N}$ and $\mathrm{P}$ contents are low and there is a need for $\mathrm{N}$ and $\mathrm{P}$ fertilization for optimal plant growth. $\mathrm{Ca}, \mathrm{Mg}$ and $\mathrm{K}$ are adequate, but there is a possibility of $\mathrm{K}$ imbalance with $\mathrm{Mg}$. Base saturation and CEC are respectively very high and high throughout the profile.

Pedon 9 is a poorly drained and stratified very deep soil with friable sandy loam topsoil overlying friable and loose subsoil layers of sandy clay loam, sandy clay and sandy textures. $\mathrm{N}$ content is low and $\mathrm{OC}$ and $\mathrm{P}$ are very low. There is a clear need for $\mathrm{N}$ and $\mathrm{P}$ fertilization for optimal crop growth. $\mathrm{Ca}, \mathrm{Mg}$ and $\mathrm{K}$ contents are adequate. Base saturation is high to very high throughout the profile while CEC is low to medium in the upper $1 \mathrm{~m}$ of the soil.

Pedon 10 is a very deep imperfectly drained soil with a firm sandy clay topsoil and a predominantly clayey subsoil. The soil has cracks as wide as $2 \mathrm{~cm}$ on the surface. The $\mathrm{N}$ content is low while the OC and P contents are very low. $\mathrm{N}$ and $\mathrm{P}$ fertilization will be necessary for optimal plant growth. $\mathrm{Ca}, \mathrm{Mg}$ and $\mathrm{K}$ are adequate. Base saturation is high to very high throughout the profile and the CEC is medium throughout the profile.

Exchangeable Na does not seem to be a problem in most of the studied soils particularly when considering the upper $100 \mathrm{~cm}$ of the soil. Exchangeable Sodium Percentage (ESP) levels are lower than the critical value of 15 for most of the soils. However, ESP may pose a 
Table 2: Chemical and physical characteristics of the studied soils

\begin{tabular}{|c|c|c|c|c|c|c|c|c|c|c|c|c|c|c|c|c|c|c|c|}
\hline \multirow{2}{*}{$\begin{array}{l}\text { Pedon } \\
\text { No. }\end{array}$} & \multirow{2}{*}{$\begin{array}{l}\text { Hori-. } \\
\text { zon }\end{array}$} & \multirow{2}{*}{$\begin{array}{l}\text { Depth } \\
\text { (cm) }\end{array}$} & \multicolumn{2}{|c|}{$\mathrm{pH}$} & \multirow{2}{*}{$\begin{array}{l}\% \\
\text { OC }\end{array}$} & \multirow{2}{*}{$\begin{array}{l}\% \\
\mathrm{OM}\end{array}$} & \multirow{2}{*}{$\begin{array}{l}\% \\
\mathrm{~N}\end{array}$} & \multirow{2}{*}{$\begin{array}{l}\mathrm{mg} / \mathrm{kg} \\
\text { Av. P }\end{array}$} & \multicolumn{5}{|c|}{ Bases and CEC $(\mathrm{cmol}(+) / \mathrm{kg}$} & \multirow{2}{*}{$\begin{array}{l}\% \\
\text { BS }\end{array}$} & \multicolumn{3}{|c|}{ \%Texture } & \multirow{2}{*}{$\begin{array}{l}\text { Text. } \\
\text { class }\end{array}$} & \multirow{2}{*}{$\begin{array}{l}B D \\
(g / c c)\end{array}$} \\
\hline & & & $\mathrm{H} 2 \mathrm{O}$ & $\mathrm{KCl}$ & & & & & $\mathrm{Ca}$ & $\mathrm{Mg}$ & $\mathrm{Na}$ & $\mathrm{K}$ & CEC & & Clay & Silt & Sand & & \\
\hline \multirow[t]{5}{*}{1} & Ap & $0-22$ & 5.5 & 4.5 & 1.8 & 3.1 & 0.22 & 4.2 & 3.25 & 2.93 & 0.21 & 0.71 & 15.3 & 46.4 & 59 & 9 & 32 & $\mathrm{C}$ & 1.12 \\
\hline & Bt1 & $22-40$ & 5 & 4 & 0.9 & 1.6 & 0.11 & 0.6 & 2.25 & 1.01 & 0.31 & 0.17 & 15.8 & 23.7 & 61 & 3 & 36 & $\mathrm{C}$ & 1.38 \\
\hline & Bt2 & $40-97$ & 4.9 & 4.1 & 0.6 & 1 & 0.07 & 0.6 & 2 & 1.46 & 0.23 & 0.17 & 11.3 & 34.2 & 65 & 3 & 32 & $\mathrm{C}$ & 1.25 \\
\hline & Bt3 & $97-153$ & 5.1 & 4.1 & 0.5 & 0.9 & 0.07 & 0.6 & 1 & 2.31 & 0.36 & 0.21 & 10.7 & 36.3 & 68 & 6 & 26 & $\mathrm{C}$ & 1.22 \\
\hline & Bt4 & $153-205^{+}$ & 5.6 & 4.2 & 0.2 & 0.3 & 0.04 & 3 & 2.05 & 2.25 & 0.36 & 0.23 & 9.3 & 52.6 & 69 & 3 & 28 & $\mathrm{C}$ & 1.25 \\
\hline \multirow[t]{7}{*}{2} & $\overline{\mathrm{Ap}}$ & $0-10$ & 5.9 & 4.8 & 1.2 & 2.1 & 0.11 & 9.8 & 2.38 & 1.21 & 0.07 & 1.69 & 11.4 & 46.9 & 37 & 7 & 56 & SC & 1.26 \\
\hline & ABmh & 20-Oct & 5.9 & 4.8 & 1.1 & 1.9 & 0.12 & 2.4 & 5.6 & 1.51 & 0.08 & 1.1 & 11.5 & 72.1 & 47 & 4 & 49 & SC & 1.6 \\
\hline & Btms & $20-55$ & 5.5 & 4.5 & 0.6 & 1 & 0.08 & 1.7 & 2.65 & 1.58 & 0.18 & 1 & 10.2 & 53 & 72 & 2 & 26 & $\mathrm{C}$ & 1.4 \\
\hline & Bt1 & $55-73$ & 5.3 & 4.6 & 0.4 & 0.7 & 0.06 & 1.3 & 2 & 1.67 & 0.25 & 0.53 & 12 & 37.1 & 61 & 2 & 37 & $\mathrm{C}$ & 1.22 \\
\hline & Bt2 & $73-113$ & 5.4 & 5 & 0.2 & 0.3 & 0.04 & 1.3 & 1.4 & 1.96 & 0.23 & 0.34 & 12.1 & 32.5 & 72 & 4 & 24 & $\mathrm{C}$ & 1.16 \\
\hline & Bt3 & $113-132$ & 5.8 & 5.4 & 0.2 & 0.3 & 0.04 & 0.8 & 2 & 2.33 & 0.1 & 0.36 & 8.4 & 57 & 71 & 2 & 27 & $\mathrm{C}$ & nd \\
\hline & $\mathrm{Bt} 4$ & $132-178$ & 5.3 & 4.6 & 0.2 & 0.3 & 0.03 & 2.2 & 1.05 & 1.17 & 0.15 & 0.76 & 8 & 39.1 & 70 & 4 & 26 & $\mathrm{C}$ & 1.24 \\
\hline \multirow[t]{6}{*}{3} & Ap & $0-14$ & 6.4 & 5.2 & 1.6 & 2.8 & 0.13 & 10.2 & 6.5 & 4.92 & 0.76 & 1.56 & 21.9 & 62.7 & 57 & 12 & 31 & $\mathrm{C}$ & 1.35 \\
\hline & BAg & $14-45$ & 6.3 & 5 & 0.7 & 1.2 & 0.09 & 1.5 & 8.63 & 6.33 & 0.64 & 0.33 & 22.4 & 71.2 & 67 & 2 & 31 & $\mathrm{C}$ & 1.42 \\
\hline & $\mathrm{Bg}$ & $45-61$ & 6.9 & 5.4 & 0.6 & 1 & 0.06 & 1.3 & 5.25 & 3.67 & 0.65 & 0.43 & 15.3 & 65.4 & 43 & 15 & 42 & $\mathrm{C}$ & 1.51 \\
\hline & $2 \mathrm{Cg}$ & $61-106$ & 6.8 & 5.2 & 0.1 & 0.2 & 0.04 & 4.5 & 2.75 & 1.21 & 0.49 & 0.26 & 5.8 & 81.2 & 13 & 1 & 86 & LS & 1.57 \\
\hline & $2 \mathrm{C}$ & $106-155$ & 7 & 5.4 & 0.1 & 0.2 & 0.01 & 1.7 & 1.38 & 0.67 & 0.54 & 0.1 & 3.8 & 70.8 & 7 & 2 & 91 & S & 1.58 \\
\hline & 3Btg & $155-180+$ & 6.6 & 6 & 0.4 & 0.7 & 0.05 & 1.5 & 6.88 & 7.33 & 0.82 & 0.38 & 21.6 & 71.3 & 57 & 2 & 41 & $\mathrm{C}$ & 1.46 \\
\hline \multirow[t]{4}{*}{4} & Apg & $0-21$ & 6.5 & 5.4 & 1.3 & 2.2 & 0.15 & 0.5 & 12 & 6.42 & 0.73 & 0.51 & 26.1 & 75.2 & 55 & 26 & 19 & $\mathrm{C}$ & 1.43 \\
\hline & $\mathrm{Bg}$ & $21-68$ & 7.7 & 6.3 & 0.7 & 1.2 & 0.07 & 0.5 & 10.55 & 8.44 & 2.03 & 0.33 & 22.5 & 94.9 & 61 & 15 & 24 & $\mathrm{C}$ & 1.49 \\
\hline & Btg1 & $68-127$ & 8.2 & 6.6 & 0.5 & 0.9 & 0.08 & 0.5 & 11.5 & 9 & 2.94 & 0.39 & 30.7 & 77.6 & 65 & 23 & 12 & $\mathrm{C}$ & 1.37 \\
\hline & Btg2 & $127-190+$ & 8.6 & 6.9 & 0.3 & 0.5 & 0.04 & 1.5 & 9.8 & 9.17 & 2.83 & 0.24 & 25.7 & 85.6 & 49 & 8 & 43 & $\mathrm{C}$ & 1.47 \\
\hline \multirow[t]{6}{*}{5} & Ap1 & $0-9$ & 5.3 & 4.2 & 1.5 & 2.6 & 0.15 & 9 & 1.28 & 1.71 & 1.47 & 3 & 15.2 & 49.1 & 20 & 7 & 73 & SCL & 1.16 \\
\hline & Ap2 & 23-Sep & 4.7 & 4.7 & 1 & 1.7 & 0.13 & 1.8 & 2 & 3.83 & 0.49 & 0.67 & 16.6 & 42.1 & 45 & 19 & 36 & $\mathrm{C}$ & 1.52 \\
\hline & BA & $23-40$ & 4.5 & 3.8 & 0.7 & 1.2 & 0.11 & 1.8 & 2 & 1.17 & 0.52 & 5.58 & 16.2 & 26.4 & 49 & 18 & 33 & $\mathrm{C}$ & 1.31 \\
\hline & Bt1 & $40-63$ & 4.9 & 3.9 & 0.4 & 0.5 & 0.08 & 1.2 & 1.25 & 1.42 & 1.68 & 0.26 & 13.8 & 33.4 & 55 & 12 & 33 & $\mathrm{C}$ & 1.2 \\
\hline & Bt2 & $63-138$ & 5.3 & 3.9 & 0.4 & 0.5 & 0.12 & 3 & 2.23 & 1.29 & 1.58 & 0.33 & 10.2 & 53.2 & 52 & 14 & 34 & $\mathrm{C}$ & 1.32 \\
\hline & Bt3 & $138-180+$ & 5.9 & 3.9 & 0.2 & 0.3 & 0.04 & 1.2 & 1.75 & 0.92 & 0.76 & 0.33 & 10.8 & 34.8 & 41 & 16 & 43 & $\mathrm{C}$ & 1.49 \\
\hline \multirow[t]{4}{*}{6} & Ap & $0-18$ & 4.8 & 3.8 & 1.2 & 2.1 & 0.13 & 3 & 4.43 & 1.17 & 1.58 & 1.43 & 13.6 & 48.6 & 43 & 3 & 54 & SC & 1.49 \\
\hline & Bt1 & $18-45$ & 4.7 & 3.8 & 0.6 & 1 & 0.08 & 1.2 & 1 & 0.8 & 0.49 & 0.3 & 12.3 & 21.3 & 63 & 4 & 33 & $\mathrm{C}$ & 1.39 \\
\hline & Bt2 & $45-105$ & 4.6 & 3.8 & 0.5 & 0.9 & 0.06 & 1.8 & 0.45 & 1.42 & 0.6 & 0.18 & 12.1 & 21.9 & 66 & 4 & 30 & $\mathrm{C}$ & 1.35 \\
\hline & Bt3 & $105-160+$ & 4.8 & 3.8 & 0.2 & 1.7 & 0.07 & 2.5 & 0.45 & 1.21 & 0.82 & 0.26 & 15 & 18.3 & 68 & 5 & 27 & $\mathrm{C}$ & 1.36 \\
\hline
\end{tabular}

problem in the deep subsoils of pedons 7, 8, 9 and 11 where it may have adverse effect not only to deep-rooted crops but also to the physical conditions of the soils.

\section{Clay mineralogy of the studied soils}

The results on the estimation of the mineralogical composition of the soil clay fractions are presented in Table 3. The mineralogy of four pedons namely, 1 (Kingolwira), 2 (Mlali), 5 (SUA Farm) and 6 (Magadu) is almost purely kaolinitic. These pedons represent the red and relatively highly weathered and friable soils of Morogoro district. The rest of the pedons are of mixed mineralogy whereby pedons 3 (Wami-Vijana Prison), 4 (Dakawa Research Station), 7 (Mkundi) and 11 (Dakawa Rice Farms) are predominantly kaolinitic but with subordinate amounts of both mica (illite) and smectite; pedon 9 (Mvomero) is also predominantly kaoinitic but with subordinate amounts of only mica (illite); pedon 8 (Melela) is largely smectitic with small amounts of kaolinite; and pedon 10 (Pangawe) is also largely smectitic but with subordinate amounts of kaolinite and traces of mica.

The pedons which are smectitic or having some amounts of smectite, present some problems of workability due 
Pedological Characteristics, General Fertility and Classification of some Benchmark Soils of Morogoro District, Tanzania

to their firm moist consistence and hard to very hard dry consistence. However, in terms of fertility they are generally more fertile (having higher CEC and BS) than the highly weathered kaolinitic soils.

Table 3. Relative mineralogical composition of clay fractions

\begin{tabular}{|llll|}
\hline Pedon & Kaolinite & Smectite & Mica/Illite \\
\hline 1 Kingolwira & +++++ & & \\
2 Mlali & +++++ & & \\
3 Wami-Vijana Prison & +++ & + & ++ \\
4 Dakawa Research Station & +++ & + & ++ \\
5 SUA Farm & +++++ & & \\
6 Magadu & +++++ & & \\
7 Mkundi & +++ & + & ++ \\
8 Melela & + & +++++ & \\
9 Mvomero & +++ & & ++ \\
10 Pangawe & ++ & +++ & tr \\
11 Dakawa Rice Farms & +++ & + & ++ \\
\hline
\end{tabular}

\section{Total chemical analysis}

On the basis of the data on total chemical analysis presented in Table 4, the following statements can be made about the soils:

(a) Pedons 1, 2, 5 and 6 can be grouped together as highly weathered soils as indicated by the low base (Ca, K, Mg and Na) content, high content of Fe, Ti and $\mathrm{Al}$ and low $\mathrm{Si} / \mathrm{Al}$ ratios.

(b) Pedons 7, 8, 9, 10, and 11 can generally be described as having high base content, low Fe and Al contents, and high $\mathrm{Si} / \mathrm{Al}$ ratios; a manifestation of a relatively lower degree of weathering. (c) Pedons 3 and 4 are high in base content and Fe and $\mathrm{Al}$ contents, and have a low $\mathrm{Si} / \mathrm{Al}$ ratio, a condition reflecting an intermediate degree of weathering

(d) The high $\mathrm{Fe} / \mathrm{Al}$ and $\mathrm{Mg} / \mathrm{K}$ ratios in pedon 9 indicate that the soil has developed from mafic parent materials while the low $\mathrm{Fe} / \mathrm{Al}$ and $\mathrm{Mg} / \mathrm{K}$ ratios in the case of pedon 7 indicate that the soil has developed from felsic parent materials.

\section{Soil classification}

Field and laboratory data (Tables 2, 3 and 4) were used to classify the soils. Table 5 presents the salient morphological and diagnostic features used in classifying the soils. Table 6 gives the soil names according to the two systems of classification used. Pedon 1 has an ochric epipedon (ochric A) and a red deep oxic horizon (ferralic B) as the diagnostic horizons and hence has been classified as an Oxisol or Ferralsol according to USDA Soil Taxonomy and FAO-Unesco Classification respectively. Oxic horizons characterize highly weathered soils.

Pedons 2, 5 and 6 have ochric epipedons and low base argillic (argic B) horizons as diagnostic horizons. The profiles show clear clay gradient between eluvial and illuvial horizons together with morphological evidence of illuviation in form of clay cutans. The soils have been classified as Ultisols or Acrisols according to USDA Soil Taxonomy and FAO-Unesco Classification respectively. Ultisols are also highly weathered soils but genetically are not as old as Oxisols.

Pedons 3 and 7 are fairly young soils with no diagnostic horizons other than an ochric epipedon, and hence have been classified as Entisols (USDA Soil Taxonomy).

Table 4. Total element analysis (\% oxides) of the studied soils

\begin{tabular}{|llllllllllll|}
\hline Pedon & $\mathrm{Fe}_{2} \mathrm{O}_{3}$ & $\mathrm{TiO}_{2}$ & $\mathrm{MnO}_{2}$ & $\mathrm{CaO}$ & $\mathrm{K}_{2} \mathrm{O}$ & $\mathrm{P}_{2} \mathrm{O}$ & $\mathrm{SiO}_{2}$ & $\mathrm{Al}_{2} \mathrm{O}_{3}$ & $\mathrm{MgO}$ & $\mathrm{Na}_{2} \mathrm{O}$ & $\mathrm{Total}$ \\
\hline 1. Kingolwira & 14.16 & 2.24 & 0.052 & 0.07 & 0.13 & 0.076 & 55.76 & 27.05 & 0.27 & 0.19 & 100 \\
2. Mlali & 11.38 & 1.51 & 0.047 & 0.07 & 0.19 & 0.061 & 60.01 & 26.5 & 0.19 & 0.05 & 100 \\
3. Wami-Vijana Prison & 13.04 & 1.3 & 0.14 & 0.92 & 1.8 & 0.054 & 53.53 & 26.24 & 1.78 & 1.22 & 100 \\
4. Dakawa Res. Station & 10.58 & 1.08 & 0.092 & 1.56 & 1.88 & 0.125 & 57.33 & 24.26 & 1.5 & 1.59 & 99.99 \\
5. SUA Farm & 15.11 & 2 & 0.057 & 0.01 & 0.47 & 0.052 & 54.32 & 27.48 & 0.24 & 0.25 & 99.99 \\
6. Magadu & 12.01 & 2.14 & 0.035 & 0 & 0.39 & 0.024 & 59.92 & 25.18 & 0.24 & 0.06 & 99.99 \\
7. Mkundi & 4.71 & 0.59 & 0.049 & 0.93 & 2.58 & 0.001 & 68.8 & 19.37 & 0.83 & 1.13 & 100 \\
8. Melela & 6.11 & 1.09 & 0.1 & 4.15 & 1.12 & 0.001 & 66.27 & 16.53 & 1.77 & 2.86 & 100 \\
9. Mvomero & 9.98 & 1.84 & 0.122 & 3.16 & 1.14 & 0.034 & 69.35 & 9.67 & 3.02 & 1.68 & 100 \\
10. Pangawe & 10.34 & 1.46 & 0.17 & 3.16 & 0.51 & 0.001 & 62.73 & 18.21 & 1.35 & 2.05 & 99.99 \\
11. Dakawa Rice Farms & 6.27 & 0.72 & 0.07 & 2.03 & 1.25 & 0.04 & 69.64 & 17.04 & 1.33 & 1.64 & 99.99 \\
\hline
\end{tabular}


Table 5. Summary of salient morphological and diagnostic features of the studied soils

\begin{tabular}{|c|c|c|c|c|c|c|}
\hline Pedon & Diagnostic horizons & Other diagnostic features & $\begin{array}{l}\text { Particle size } \\
\text { class }\end{array}$ & $\begin{array}{l}\text { Calcareousness and } \\
\text { reaction class }\end{array}$ & Soil depth & Mineralogy class \\
\hline 1 Kingolwira & $\begin{array}{l}\text { Ochric epipedon } \\
\left(*^{*} \text { ochric A); }\right. \\
\text { Oxic horizon } \\
(* \text { ferralic B) }\end{array}$ & $\begin{array}{l}\text { Iso-hyperthermic STR; ustic SMR; thick horizon with } \\
\text { CEC=or }<16 \mathrm{cmol}+/ \mathrm{kg} \text { clay; diffuse particle size boundary; } \\
\text { *very low silt-clay ratio }<0.2 \text {; *no rock structure; }>40 \% \text { clay in } \\
\text { the surface } 18 \mathrm{~cm} \text {; color hue of } 2.5 \text { YR or redder with moist } \\
\text { values of }<4 \text { (*red to dus ky red ferralic B) }\end{array}$ & $\begin{array}{l}\text { Very fine } \\
\text { clayey }\end{array}$ & Acid & Very deep & Kaolinitic \\
\hline 2 Mlali & $\begin{array}{l}\text { Ochric epipedon } \\
\left({ }^{*} \text { ochric A); }\right. \\
\text { Argillic horizon } \\
\left({ }^{*} \text { argic B) }\right.\end{array}$ & $\begin{array}{l}\text { Iso-hyperthermic STR; ustic SMR; appreciable clay gradient } \\
\text { between eluvial and illuvial layer; clay cutans; } \mathrm{CEC}=\mathrm{or}<16 \\
\text { cmol+/kg clay in major part of argillic } \mathrm{B}\left({ }^{*} \mathrm{CEC}=\mathrm{or}<24 \mathrm{cmol}+/ \mathrm{kg}\right. \\
\text { clay in argic B); *BS }<50 \% \text { in some parts of argic B; low OM } \\
\text { content; normal }\end{array}$ & $\begin{array}{l}\text { Very fine } \\
\text { clayey }\end{array}$ & Acid & Very deep & Kaolinitic \\
\hline 3 Wami-Vijana Pris on & $\begin{array}{l}\text { Ochric epipedon } \\
(* \text { ochric A) }\end{array}$ & $\begin{array}{l}\text { Iso-hyperthermic STR; aquic SMR }(* \text { gleyic properties), } \\
\text { Slope }<25 \% \text {; *Fluvic properties (stratification, alluvial } \\
\text { deposits, OC decreases irregularly with depth); *BS=or }>50 \% \\
\text { between } 20-50 \mathrm{~cm} \text {; cracks during dry season }\end{array}$ & $\begin{array}{l}\text { Clayey over } \\
\text { sandy }\end{array}$ & $\begin{array}{l}\text { Non-acid, non- } \\
\text { calcareous }\end{array}$ & Very deep & $\begin{array}{l}\text { Mixed (kaolinite, } \\
\text { mica, smectite) }\end{array}$ \\
\hline 4 Dakawa Res. Station & $\begin{array}{l}\text { Ochric horizon } \\
(* \text { ochric A); } \\
\text { Cambic horizon } \\
(* \text { cambic B) }\end{array}$ & $\begin{array}{l}\text { Iso-hyperthermic STR; aquic SMR (*gleyic properties); } \\
\text { cracks during dry season }\end{array}$ & $\begin{array}{l}\text { Very fine } \\
\text { clayey }\end{array}$ & $\begin{array}{l}\text { Non-acid, non- } \\
\text { calcareous }\end{array}$ & Very deep & $\begin{array}{l}\text { Mixed (kaolinite, } \\
\text { mica, smectite) }\end{array}$ \\
\hline 5 SUA Farm & $\begin{array}{l}\text { Ochric epipedon } \\
\left({ }^{*} \text { ochric A); }\right. \\
\text { Argillic horizon } \\
\text { (*argic B) }\end{array}$ & $\begin{array}{l}\text { Iso-hyperthermic STR, ustic SMR; appreciable clay gradient } \\
\text { between eluvial and illuvial horizon; clay cutans; low BS }<35 \% \\
\text { by sum of cations; } \mathrm{CEC}<24 \mathrm{cmol}+/ \mathrm{kg} \text { clay in major part of } \\
\text { argillic horizon }\end{array}$ & Fine clayey & Acid & Very deep & Kaolinitic \\
\hline 6 Magadu & $\begin{array}{l}\text { Ochric epipedon } \\
\left({ }^{*} \text { ochric A); }\right. \\
\text { Argillic horizon } \\
\text { (*argic B) }\end{array}$ & $\begin{array}{l}\text { Iso-hyperthermic STR; ustic SMR; appreciable clay gradient } \\
\text { between eluvial and illuvial horizon; clay cutans; low BS }<35 \% \\
\text { by sum of cations ( } * \mathrm{BS}<50 \% \text { in argic B); } \mathrm{CEC}<24 \mathrm{cmol}+/ \mathrm{kg} \\
\text { clay in major part of argillic horizon }\end{array}$ & $\begin{array}{l}\text { Very fine } \\
\text { clayey }\end{array}$ & Acid & Very deep & Kaolinitic \\
\hline 7 Mkundi & $\begin{array}{l}\text { Ochric epipedon } \\
\text { (*ochric A) }\end{array}$ & $\begin{array}{l}\text { Iso-hyperthermic STR; aquic SMR }(* \text { gleyic properties }) \text {; } \\
* \mathrm{BS}<50 \% \text { between } 20-50 \mathrm{~cm}\end{array}$ & $\begin{array}{l}\text { Very fine } \\
\text { clayey }\end{array}$ & Acid & Very deep & $\begin{array}{l}\text { Mixed (kaolinite, } \\
\text { mica, smectite) }\end{array}$ \\
\hline 8 Melela & $\begin{array}{l}\text { Ochric epipedon } \\
\left(*^{*} \text { ochric A) }\right.\end{array}$ & $\begin{array}{l}\text { Iso-hyperthermic STR; ustic SMR; }>30 \% \text { clay in the upper } \\
18 \mathrm{~cm}(*>35 \% \text { clay in all horizons); wide deep cracks; gilgai } \\
\text { micro-relief; slickensides; prismatic structure; *BS>50\%; } \\
\text { effervescence with } \mathrm{HCl} \text { (*calcareous) }\end{array}$ & Fine clayey & Non-acid, calcareous & Very deep & Smectitic \\
\hline 9 Mvomero & $\begin{array}{l}\text { Mollic epipedon } \\
(* \text { mollic A) }\end{array}$ & $\begin{array}{l}\text { Iso-hyperthermic STR; aquic SMR (*gleyic properties); dark } \\
\text { colored epipedon meeting all the requirements of mollic epi- } \\
\text { pedon; BS }>50 \% \text { throughout the profile; * fluvic properties } \\
\text { (stratification, OC decreases irregularly with depth); slope } \\
<25 \%\end{array}$ & $\begin{array}{l}\text { Clayey over } \\
\text { sandy }\end{array}$ & $\begin{array}{l}\text { Non-acid, non- } \\
\text { calcareous }\end{array}$ & Very deep & $\begin{array}{l}\text { Mixed (kaolinite, } \\
\text { mica) }\end{array}$ \\
\hline 10 Pangawe & $\begin{array}{l}\text { Ochric epipedon } \\
\left({ }^{*} \text { ochric A); }\right. \\
\text { Argillic horizon } \\
\text { (*argic B) }\end{array}$ & $\begin{array}{l}\text { Iso-hyperthermic STR; aquic SMR }\left({ }^{*} \text { gleyic properties); }\right. \\
\text { appreciable clay gradient between eluvial and illuvial horizon; } \\
\text { clay cutans; some vertic properties (cracks on the surface); } \\
\text { *high BS }>50 \% \text { and high CEC = or }>24 \mathrm{cmol}+/ \text { kg clay in B } \\
\text { horizon }\end{array}$ & Fine clayey & $\begin{array}{l}\text { Non-acid, non- } \\
\text { calcareous }\end{array}$ & Very deep & Smectitic \\
\hline 11 Dakawa Rice Farms & $\begin{array}{l}\text { Ochric epipedon } \\
\text { (*ochric A); } \\
\text { Cambic horizon } \\
\left({ }^{*} \text { cambic B) }\right.\end{array}$ & $\begin{array}{l}\text { Iso-hyperthermic STR; aquic SMR (*gleyic properties); } \\
\text { *calcaric -presence of lime; vertic properties (slickensides, } \\
\text { wide deep cracks); *>35\% clay in all sub-horizons to a depth } \\
\text { of } 5 \mathrm{~cm}\end{array}$ & Fine clayey & Non-acid, calcareous & Very deep & $\begin{array}{l}\text { Mixed (kaolinite, } \\
\text { mica, smectite) }\end{array}$ \\
\hline
\end{tabular}

NB.* terminology particularly used in the FAO-UNESCO Classification; those without * are used in the USDA Soil Taxonomy

However, due to differences in parent materials and modes of formation they have different characteristics. According to the FAO-Unesco Classification System, pedon 3 which is a river deposited soil and showing all evidences of fluvic properties is classified as a Fluvisol while pedon 7 is classified as a Regosol.

Pedon 4 is genetically more developed than pedons 3 and 7 as exhibited by the presence of both an ochric epipedon and a cambic horizon (cambic B). This soil has been classified as an Inceptisol (USDA Soil Taxonomy) or a Cambisol (FAO-Unesco Classification). Inceptisols are soils that have just started to form as may be indicated by modest development of structure, color, consistence etc. They are therefore younger than Ultisols and Oxisols.

Pedons 8 and 11 have ochric epipedons as diagnostic horizons and are also characterized by the presence of vertic characteristics including slickensides, deep wide 
Pedological Characteristics, General Fertility and Classification of some Benchmark Soils of Morogoro District, Tanzania

Table 6: Classification of the studied soils

\begin{tabular}{|c|c|c|c|c|c|c|c|}
\hline \multirow[t]{2}{*}{ Pedon } & \multicolumn{5}{|c|}{ USDA Soil Taxonomy } & \multicolumn{2}{|c|}{ FAO-Unesco Classification } \\
\hline & Order & Suborder & Greatgroup & Subgroup & Family & Level-1 & Level-2 \\
\hline 1 Kingolwira & Oxisol & Ustox & Haplustox & Rhodic Haplustox & $\begin{array}{l}\text { Very fine clayey, acid, iso- } \\
\text { hyperthermic, deep, kaolinitic, } \\
\text { Rhodic Haplustox }\end{array}$ & Ferralsol & $\begin{array}{l}\text { Rhodic } \\
\text { Ferralsol(FRr) }\end{array}$ \\
\hline 2 Mlali & Ultis ol & Ustult & Kanhaplustult & Typic Kanhaplustult & $\begin{array}{l}\text { Very fine clayey, acid, iso- } \\
\text { hyperthermic, deep, kaolinitic, } \\
\text { Typic Kanhaplustult }\end{array}$ & Acrisol & Haplic Acrisol(ACh) \\
\hline 3 Wami-Vijana Pris on & Entisol & Aquent & Fluvaquent & Vertic Fluvaquent & $\begin{array}{l}\text { Clayey over sandy, non-acid, non- } \\
\text { calcareous, iso-hyperthermic, deep, } \\
\text { mixed,Vertic Fluvaquent }\end{array}$ & Fluvisol & Eutric Fluvisol(FLe) \\
\hline 4 Dakawa Research Station & Inceptisol & Aquept & Tropaquept & Vertic Tropaquept & $\begin{array}{l}\text { Very fine clayey, non-acid, non- } \\
\text { calcareous, iso-hyperthermic, deep, } \\
\text { mixed, Vertic Tropaquept }\end{array}$ & Cambisol & $\begin{array}{l}\text { Gleyic } \\
\text { Cambisol(CMg) }\end{array}$ \\
\hline 5 SUA Farm & Ultis ol & Ustult & Haplustult & Kanhaplic Haplustult & $\begin{array}{l}\text { Fine clayey, acid ,iso- } \\
\text { hyperthermic, deep, kaolinitic, } \\
\text { Kanhaplic Haplustult }\end{array}$ & Acrisol & Haplic Acrisol(ACh) \\
\hline 6 Magadu & Ultis ol & Ustult & Haplustult & Kanhaplic Haplustult & $\begin{array}{l}\text { Very fine clayey, acid, iso- } \\
\text { hyperthermic, deep, kaolinitic, } \\
\text { Kanhaplic Haplustult }\end{array}$ & Acrisol & Haplic Acrisol(ACh) \\
\hline 7 Mkundi & Entisol & Aquent & Tropaquent & $*$ & $\begin{array}{l}\text { Very fine clayey, acid, iso- } \\
\text { hyperthermic, deep, mixed, } \\
\text { Tropaquent }\end{array}$ & Regosol & $\begin{array}{l}\text { Dystric Regosol } \\
(R G d)\end{array}$ \\
\hline 8 Melela & Vertisol & Ustert & Pellustert & Paleustollic Pellustert & $\begin{array}{l}\text { Fine clayey, non-acid, calcareous, } \\
\text { iso-hyperthermic, deep, mixed, } \\
\text { Typic Pellustert }\end{array}$ & Vertisol & Eutric Vertisol(VRe) \\
\hline 9 Mvomero & Mollis ol & Aquoll & Haplaquoll & $\begin{array}{l}\text { Fluvaquentic } \\
\text { Haplaquoll }\end{array}$ & $\begin{array}{l}\text { Clayey over sandy, non-acid, non- } \\
\text { calcareous, iso-hyperthermic, deep, } \\
\text { mixed, Fluvaquentic Haplaquoll }\end{array}$ & Fluvisol & Eutric Fluvisol(FLe) \\
\hline 10 Pangawe & Alfisol & Aqualf & Ochraqualf & Vertic Ochraqualf & $\begin{array}{l}\text { Fine clayey, non-acid, non- } \\
\text { calcareous, iso-hyperthermic, deep, } \\
\text { smectitic, Vertic Ochraqualf }\end{array}$ & Luvisol & Vertic Luvisol (LVv) \\
\hline 11 Dakawa Rice Farms & Vertisol & Ustert & Pellustert & Typic Pellustert & $\begin{array}{l}\text { Fine clayey, non-acid, calcareous, } \\
\text { iso-hyperthermic, deep, mixed, } \\
\text { Typic Pellustert }\end{array}$ & Vertisol & $\begin{array}{l}\text { Calcic Vertisol } \\
(\text { VRk) }\end{array}$ \\
\hline
\end{tabular}

cracks and gilgai micro-relief. In these soils there is constant physical and biological churning of the soil materials thereby resulting in partial inversion of the soils and homogenization of the profiles. Pedon 11 has also a cambic horizon which is to some degree being masked by the vertic characteristics. The two pedons have been classified as Vertisols in both USDA Soil Taxonomy and FAO-Unesco Classification Systems. Genetically Vertisols do not have much possibility of development because of the regular pedoturbation taking place in them. In terms of age these soils could roughly be compared with Inceptisols.

Pedon 9 has a mollic epipedon (mollic A) as the diagnostic epipedon and has been classified as a Mollisol (USDA Soil Taxonomy) or a Fluvisol (FAO-Unesco Classification) since its mode of formation is fluvial. Mollisols are by definition good soils with soft structure and high inherent fertility (high OM content and high BS). These soils are not highly weathered and their relative pedogenic age may range between that of Entisols and Inceptisols.

Pedon 10 has ochric epipedon and high base argillic horizon (argic B) as the diagnostic horizons and has therefore been classified as an Alfisol (USDA Soil Taxonomy or a Luvisol (FAO-Unesco Classification). Alfisols are soils with a high base illuvial (argillic) horizon. Like the Ultisols, Alfisols must have all the evidences of eluviation-illuviation processes including appreciable clay gradient between eluvial and illuvial layers, and presence of clay skins (argillans) in the illuvial layer. In terms of age, Alfisols are slightly younger than Ultisols but older than the Inceptisols, Mollisols, Vertisols and Entisols. 


\section{CONCLUSIONS AND RECOMMENDATIONS}

1. The studied soils have varying properties and can be classified into soil categories with different potentials and constraints to use and management.

2. Pedons 1, 2, 5 and 6 are highly weathered kaolinitc soils with low chemical fertility. Non-acidifying $\mathrm{N}$ and $\mathrm{P}$ fertilizers and liming are deemed necessary for optimal crop production.

3. Pedons 3, 4, 10 and 11 have high chemical fertility as indicated by high BS and CEC values. However, their vertic characteristics and very hard consistence pose problems of difficult workability. Moreover $\mathrm{N}$ and $\mathrm{P}$ contents are low and there is need for fertilization.

4. Pedon 7 has low topsoil BS and CEC and low to very low $\mathrm{N}$ and $\mathrm{P}$ contents. Substantial $\mathrm{N}$ and $\mathrm{P}$ fertilization is required to supply $\mathrm{N}$ and $\mathrm{P}$.

5. Pedon 8 like pedons 3, 4, 10 and 11, has high BS and CEC and hence can be said to be of high chemical fertility status. It has more pronounced vertic characteristics manifested by wide deep cracking typical of the smectitic mineralogy. Difficult workability due to the soil's firm consistence poses a big problem.

6. Pedon 9 is a friable soil with a soft structure offering easy workability. The BS is high to very high throughout the soil profile while the CEC is low to medium in the upper $1 \mathrm{~m}$ of the profile. $\mathrm{N}$ and $\mathrm{P}$ fertilization is required due to the low levels of these nutrients in the soil.

\section{ACKNOWLEDGEMENTS}

The authors wish to express their sincere thanks to the Canadian International Development Agency (CIDA) for financing this work which was part of a major project on "Development of Soil Fertility Research Capability and Soil Sampling Protocols for Benchmark Soils in Tanzania”.

\section{REFERENCES}

Baize, D. (1993). Soil science analyses. A guide to current use. John Wiley \& Sons Ltd., West Sussex. 192pp.
Blake, G.R. (1964). Bulk density. In: Methods of Soil Analysis, part 1 (eds. C.A Black, D.D. Evans, J.L. White, L.E. Ensminger and F.E. Clark), pp. 374390. ASA, Madison, Wisconsin.

Bray, R.H. and Kurtz, L.T. (1945). Determination of total, organic and available forms of phosphorus in soils. Soil Sci: 59:39-45.

Bremner, J.M. and Mulvaney, C.S. (1982). Total nitrogen. In: Methods of Soil Analysis, part 2, 2nd edit. (eds. A.L. Page, R.H. Miller and D.R. Keeney), PP 595624. ASA, SSSA Monograph no. 9, Madison, Wisconsin.

Day, P.R. (1965). Particle fractionation and particle size analysis. In: Methods of Soil Analysis, part 1, (eds. C.A. Black, D.D. Evans, J.L. White, L.E. Ensminger and F.E. Clark), pp.545-566. A S A, M a d i s o n, Wisconsin.

De Pauw, E. (1984). Soils, physiography and agroecological zones of Tanzania. Ministry of Agriculture and Food and Agriculture Organization (FAO), Dar es Salaam.

Dixon, J.B. and Weed, S.B. (eds) (1989). Minerals in soil environment. $2^{\text {nd }}$ edition. Soil Sci. Soc. Am., Madison, Wisconsin, pp. 1051 - 1087

EUROCONSULT (1989). Agricultural compendium for rural development in the tropics and subtropics. Elsevier Science Publishers, Amsterdam. 740 pp.

FAO (1977). Guidelines for soil profile description 2nd edition. Soil Resource Development and Conservation Service, Land and Water Development Division, FAO, Rome. 66 pp.

FAO-Unesco (1989). Soil map of the world, revised legend. International Soil Reference and Information Centre, Wageningen. 138 pp.

Kaaya, A.K., Msanya, B.M. and Mrema, J.P. (1994). Soils and land evaluation of part of the Sokoine University of Agriculture Farm Tanzania, for some crops under rained conditions. African Study Monographs, 15(2):97-118. Kyoto University.

Kilasara, M., Magoggo, J.P. and Msanya, B.M. (1994). Land resource management in Tanzania. In: Tarimo, A.J.P., D.F. Rutatora and A.Z. Mattee (editors). Towards Developing a Programme Research for the Faculty of Agriculture to the Year 2000. Proceedings of the Faculty of Agriculture Research Workshop held at the Institute of Continuing Education, Sokoine University of Agriculture, Tanzania 21st - 23rd March 1993, Morogoro, Tanzania. 
Pedological Characteristics, General Fertility and Classification of some Benchmark Soils of Morogoro District, Tanzania

Kimaro, D.N., Msanya, B.M., Mwango, S.B., Kimbi, G.G. and Kileo, E.P. (2001). Land suitability evaluation for the production of the major crops in the Southwestern part of the Uluguru Mountains, Morogoro Rural District, Tanzania. Soils and Land Resources of Morogoro Rural and Urban Districts, Vol. 2. Sokoine University of Agriculture, Morogoro. ISBN 9987605273.

Kucey, K. (1990). A comparison of two soil profiles of the Morogoro Region, Tanzania; with af o c u s o n their relative suitabilities for Zea mays production. MSc preliminary project work, Macdonald College, McGill University.

Landon, J.R. (1991) (editor). Booker Tropical Soil Manual. A handbook for soil survey and agricultural land evaluation in the tropics and subtropics. Longman Scientific \& Technical Publishers, Essex. 474 pp.

Magoggo, J.P. (1983). Soil survey report of selected areas in the Mkata Plain: Kilangali, Mvumi and Mgongola village irrigation schemes. Detailed Soil Survey Report D3. National Soil Service, Agricultural Research Institute, Mlingano, Tanga, Tanzania.

Moberg, J.P., Msanya, B.M. and Kilasara, M. (1982). Pedological and edaphological properties of the soils of two soil associations in the Morogoro Area, Tanzania. Trop. Agric. (Trinidad) 59(2):139-148.

Msanya, B.M. (1980). Study of the soils of a toposequence on metasedimentary rocks of the Morogoro Region (Tanzania), with special attention to texture determination and soil classification. MSc (Soil Science) thesis, State University of Ghent, Belgium.

Msanya, B.M. (1991). Soils of Allidina and Lutindi Estates in Kilosa District and their agricultural potential. Consultant report, Department of Soil Science, Sokoine University of Agriculture, Morogoro, Tanzania.

Msanya, B.M. and Msaky, J.J. (1983). Mineralogy of some soils developed on metasedimentary rocks of Morogoro Region, Tanzania. Beiträge Trop. Landwirtsch. Veterinärmed. 21(2):181-189.

Msanya, B.M., Msaky, J.J., Takamura, Y.T. and Araki, S. (1991). Land use and land evaluation systems research in Tanzania. A project proposal submitted to the Japan InternationalCooperation Agency (JICA), Tokyo Office, Japan.

Msanya, B.M. and Magoggo, J.P. (1993). Review of Soil Surveys (Soil Resource Inventories) inTanzania. Ecology and Development Programme, The Agricultural University of Norway, ISSN 0804 2144, A ${ }^{0}$ s, Norway.
Msanya, B.M., Kimaro, D.N. and Araki, S. (1998). Characteristics of two pedons and their implication for environmental management in part of Mbinga District, Tanzania. Tanzania Journal of Agricultural Sciences 1(1):64-70.

Msanya, B.M., Kimaro, D.N., Kileo, E.P., Kimbi, G.G. and Mwango, S.B. (2001a). Land suitability evaluation for the production of food crops and extensive grazing: a case study of Wami Plains in Morogoro Rural District, Tanzania. Soils and land Resources of Morogoro Rural and Urban Districts, Vol. 1. Sokoine University of Agriculture, Morogoro. ISBN 9987605265.

Msanya, B.M., Kimaro, D.N., Kileo, E.P., Kimbi, G.G. and Munisi, A.I.M. (2001b). Land resources inventory and suitability assessment for the production of the major crops in eastern part of Morogoro Rural District, Tanzania. Soils and Land Resources of Morogoro Rural and Urban Districts.Vol. 3. Sokoine University of Agriculture, Morogoro. ISBN 998760528 1. Msanya, B.M., Kimaro, D.N., Kimbi, G.G., Kileo, E.P. and Mbogoni, J.D.J. (2001c). Land resources inventory and suitability assessment for the major land use types in Morogoro Urban District, Tanzania. Soils and Land Resources of Morogoro Rural and Urban Districts, Vol. 4. Morogoro. ISBN 998760529 X.

Munsell Color Company (1954). Munsell Soil Color Charts. Munsell Color Co. Inc. Baltimore.

Murphy, J. and Riley, J.P. (1962). A modified single solution method for determination of phosphate in natural waters. Anal. Chim. Acta 27:31-36.

National Soil Service (1986). Soils and land suitability for irrigated rice cultivation of the Mkindo Village Irrigation Scheme, Morogoro. Detailed Soil Survey Report D5. Agricultural Research Institute, Mlingano, Tanga, Tanzania.

National Soil Service (1988). Soils of Tungi Estate and their potential for hybrid sisal cultivation.Semidetailed soil survey report D16.Agricultural Research Institute, Mlingano, Tanga, Tanzania.

Nelson, D.W. and Sommers, L.E. (1982). Total carbon, organic carbon and organic matter. In: Methods of Soil Analysis, part 2, 2nd edit. (eds. A.L. Page, R.H. Miller and D.R. Keeney), PP. 539-579. ASA, SSSA Monograph no. 9, Madison, Wisconsin.

Soil Survey Staff (1990). Keys to Soil Taxonomy. Agency for International Development, United States Department of Agriculture. Soil Management Support Services Technical Monograph no. 19. Virginia Polytechnic Institute and State University. 422 pp. 